\title{
The first Mesozoic Derbidae (Homoptera: Fulgoroidea) from Cretaceous Burmese amber
}

\author{
Первые мезозойские Derbidae (Homoptera: Fulgoroidea) \\ из мелового бирманского янтаря
}

\author{
A.F. Emeljanov ${ }^{1}$, D.E. Shcherbakov ${ }^{2}$ \\ А.Ф. Емельянов ${ }^{1}$, А.Е. Щербаков ${ }^{2}$
}

\footnotetext{
${ }^{1}$ Zoological Institute, Russian Academy of Sciences, Universitetskaya Emb. 1, St.-Petersburg 199034, Russia. E-mail: alexandr.emeljanov@zin.ru.

${ }^{2}$ Borissiak Paleontological Institute, Russian Academy of Sciences, Profsoyuznaya St. 123, Moscow, 117647, Russia. E-mail: dshh@narod.ru.

1 Зоологический институт РАН, Университетская наб. 1, Санкт-Петербург 199034, Россия.

2 Палеонтологический институт им. А.А. Борисяка РАН, ул. Профсоюзная 123, Москва 117647, Россия.
}

KEY WORDS: planthoppers, Achilidae, sensory pits, phylogeny, fossil, Cenozoic.

КЛЮЧЕВЫЕ СЛОВА: носатки, Achilidae, сенсорные ямки, филогения, ископаемые, кайнозой.

ABSTRACT. Derbachile hochae gen. et sp.n., D. aschei sp.n. and Achiderbe obrienae gen. et sp.n. from mid-Cretaceous Burmese amber described in Derbachilini trib.n. are the first Mesozoic and the earliest fossil Derbidae. D. hochae sp.n., with $2.6 \mathrm{~mm}$ tegmina, is one of the smallest derbids known. Like their modern relatives, Burmite derbids could feed on monocots and woody dicots, and their nymphs could dwell in rotting wood and plant debris. Transformation of achilid-like ancestors into typical derbids is discussed. The new tribe combines achilid facies of primitive derbids with some characters of more advanced tribes, such as sensory pits on the costal vein in tegmen, narrow face, flattened antennae and subantennal carina. The tribe is assigned to the primitive subfamily, which is renamed Breddiniolinae Fennah, 1950, stat.n. (= Cedusinae Emeljanov, 1992, syn.n.) by priority.

РЕЗЮМЕ. Derbachile hochae gen. et sp.n., D. aschei sp.n. и Achiderbe obrienae gen. et sp.n. из среднемелового бирманского янтаря описаны в составе Derbachilini trib.n. Это первые мезозойские и древнейшие ископаемые семейства Derbidae. $D$. hochae sp.n. с передними крыльями 2.6 мм - одна из мельчайших известных дербид. Подобно современным дербидам, меловые могли питаться на однодольных и древесных двудольных, а их личинки — обитать в гниющей древесине и растительном опаде. Обсуждается преобразование подобных ахилидам предков в типичных дербид. Новая триба сочетает ахилидные черты примитивных дербид с некоторыми признаками более продвинутых триб, такими как сенсорные ямки на костальной жилке переднего крыла, узкое лицо, уплощённые усики и подусиковый киль. Эта триба отнесена к примитивному подсемейству, название которого, согласно приоритету, изменено на Breddiniolinae Fennah, 1950, stat.n. (= Cedusinae Emeljanov, 1992, syn.n.).

Derbidae, with more than 160 described genera and almost 1,700 species, is the third most diverse planthopper family after Cixiidae and Delphacidae [Bourgoin, 2020], having a higher proportion of diversity in the tropics than the latter two families. The family is currently divided into three subfamilies and 21 tribes [Bourgoin, 2020]. Derbids are structurally diverse: the higher tribes are easily recognizable by their peculiar appearance, while the most primitive ones often look like Achilidae, so that the assignment of three tribes to Derbidae has yet to be confirmed by studying their male genitalia.

The fossil record of Derbidae is rather scarce, and until now has been limited to the Cenozoic. Currently only five of the extant tribes are recorded from ambers and sedimentary rocks (Cedusini, Cenchreini, Derbini, Otiocerini, Zoraidini) [Emeljanov, 1994, 2002, 2008a; Emeljanov, Shcherbakov, 2000; Stroiński, Szwedo, 2002; Szwedo, 2004a, 2005, 2006]. The extinct tribe Ptychoptilini from Eocene Baltic amber, described in Achilidae [Emeljanov, 1990], was related to the derbid tribes Ipsnolini and Vinatini by Szwedo and Stroiński [2001], and therefore moved to Derbidae [Bourgoin, 2020]. The alleged Triassic find does not belong to the family [Emeljanov, 1994].

Mid-Cretaceous Burmese amber, formed on an island in the tropical ocean Tethys between Gondwana and Laurasia [Westerweel et al., 2019], contains a rich insect

How to cite this article: Emeljanov A.F., Shcherbakov D.E. 2020. The first Mesozoic Derbidae (Homoptera: Fulgoroidea) from Cretaceous Burmese amber // Russian Entomol. J. Vol.29. No.3. P.237-246. doi: 10.15298/ rusentj.29.3.02 
fauna. This amber was dated to the early Cenomanian ( 99 Ma) [Shi et al., 2012], but it has recently been shown that ambers from some mines are much older or younger (from early Albian to late Campanian, 110-72 Ma) [Xing, Qiu, 2020]. Among diverse Burmite Fulgoroidea, there are four endemic families (Dorytocidae, Yetkhatidae, Jubisentidae, Katlasidae) [Emeljanov, Shcherbakov, 2018; Song et al., 2019; Zhang et al., 2019; Luo et al., 2020b], three widespread Cretaceous families (Perforissidae, Mimarachnidae, Neazoniidae) [Shcherbakov, 2007a, b, 2017; Zhang et al., 2017; Jiang et al., 2018; Luo et al., 2020a; etc.], and a few extant families, such as Cixiidae and Achilidae [Shcherbakov, 2000; Szwedo, 2004b]. Upon closer inspection, some of Burmite achilid-like fossils turned out to be very primitive derbids. They are described below as a new tribe.

The type specimens are deposited at Borissiak Paleontological Institute, Russian Academy of Sciences, Moscow (PIN). Photographs were taken using a Leica M165C stereomicroscope with a Leica DFC425 digital camera and z-stacked with Helicon Focus 7.0. The specimens were also examined under a Zeiss Axioplan 2 microscope with a Zeiss Axiocam 105 digital camera. Nomenclature of the planthopper cranium is given after Anufriev and Emeljanov [1988].

Family Derbidae Spinola, 1839

Subfamily Breddiniolinae Fennah, 1950, stat.n.

= Cedusinae Emeljanov, 1992, syn.n.

TYPE GENUS: Breddiniola Muir, 1934.

COMPOSITION. Breddiniolini Fennah, 1950; Ptychoptilini Emeljanov, 1990; Vinatini Emeljanov, 1992; Cedusini Emeljanov, 1992; Ipsnolini Emeljanov, 1995; Goneokarellini Emeljanov, 1995; Phrygiini Emeljanov, 1995; Derbachilini trib.n.

Tribe Derbachilini Emeljanov et Shcherbakov, trib.n.

TYPE GENUS: Derbachile gen.n.

DIAGNOSIS. Tegmina long (tegmen length greater than body length), shallowly tectiform in repose, with achilid-like venation, shallowly convex costal margin, longitudinal branches of $\mathrm{M}$ and $\mathrm{CuA}, \mathrm{CuA} 2$ terminating on apical margin, apically truncate clavus about $1 / 2$ wing length, and sensory pits on $\mathrm{C}$. Hind wing with ScRA long, $M$ forking before crossveins, and 3-branched $\mathrm{CuA}$. Pedicel somewhat enlarged and flattened. Subantennal ridge low or absent. Apical segment of rostrum long.

COMPOSITION. Type genus and Achiderbe gen.n.

REMARKS. The new tribe combines the primitive structure of the hind wing and rostrum with a few characters of moderately derived Derbidae (sensory pits on C, enlarged flattened antennae). The type genus shows also the narrowed metope and primitive structure of pronotum and hind legs, and its type species, a rudimentary subantennal ridge. Such a character combination is unknown in other Derbidae (see Discussion).

Genus Derbachile Emeljanov et Shcherbakov, gen.n.

TYPE SPECIES: Derbachile hochae Emeljanov et Shcherbakov, sp.n.

DIAGNOSIS. Small, slender. Tegmen with achilid-like venation, elongated, much widened distally, clavus less than $1 / 2$ wing length. $C$ with sensory pits at base and along anterior margin; ScR and $\mathrm{M}$ forming short stalk beyond basal cell; ScR forking earlier than $\mathrm{CuA}$; stigmal cell darkened; RA2 with short fork, RA2a recurrent, RP simple; $M$ with 4 terminations, MA forking much earlier than MP, medial cell narrow, medial apical cells long; $\mathrm{CuA} 1$ and $\mathrm{CuA} 2$ connected by crossvein icua distal to $2 m \mathrm{cu}, \mathrm{CuA} 1$ bent at $2 m-\mathrm{cu}$ and icua, 1 st procubital cell long and wide distally; $\mathrm{CuA} 2$ distant from posterior margin and reaching apical margin; crossvein on clavus between $\mathrm{CuP}$ and Pcu. Hind wing broad, RP simple, $\mathrm{M}$ forking before crossveins $\mathrm{r}-\mathrm{m}$ and $\mathrm{m}-\mathrm{cu}, \mathrm{CuA}$ with 3 terminations. Pedicel enlarged, more or less flattened. Metope narrow dorsally. Lateral ocelli present. Subantennal ridge low or absent. Rostrum surpassing mid coxae, apical segment more than thrice longer than wide. Pronotum with strongly elevated, long, triangular, tricarinate disc occupying almost $1 / 2$ width. Mesonotum with lateral discal carinae strongly converging anteriorly, median carina weak or absent. Legs long, slender. Hind tibia with $2-3$ lateral teeth (1st minute, at base) and 8-11 apical teeth, tarsomere I with 6-9, II with 4-6 apical teeth, without discernible subapical setae. COMPOSITION. Type species and D. aschei sp.n.

ETYMOLOGY. Free combination of generic names Derbe and Achilus; gender feminine.

\section{Derbachile hochae Emeljanov et Shcherbakov, sp.n.} Figs 1-10, 27.

MATERIAL. Holotype PIN 5608/134, $\sigma^{7}$ - Burmese amber, Hukawng Valley, Kachin State, Myanmar; mid-Cretaceous (probably Albian-Cenomanian).

DIAGNOSIS. Wings hyaline; body pale, disc of mesonotum dark; legs pale with dark streaks; median carina of mesonotum absent; hind tibia with 2 lateral teeth.

DESCRIPTION. Tegmen $2.6 \mathrm{~mm}$ long, ca. $1.0 \mathrm{~mm}$ wide, elongate, much widened distally, 2.5:1, hyaline, slightly infuscate along anterior margin, veins and stigmal cell fuscous. Anterior margin shallowly convex, with slight concavity at nodus; apical margin rounded. Costal vein turning flat, transversely corrugate distad of ScR fork; C and ambient vein with sensory pits up to apex of tegmen. ScR fork slightly proximad of, and $\mathrm{CuA}$ fork distad of, union of claval veins. Nodal $r-m$ distal to nodal $m-c u$. MA fork about halfway from nodal $r-m$ to $2 r-m$. Medial cell long and narrow, about as large as cell distal to it and twice larger than cell anterodistal to it. Crossvein on clavus between $\mathrm{CuP}$ and Pcu before middle. Clavus truncate at apex. Hind wing $2.2 \mathrm{~mm}$ long, $1.1 \mathrm{~mm}$ wide, relatively large, 0.8 as long as tegmen, and moderately broad, $2.0: 1$, apex distinctly not reaching apex of tegmen in repose; membrane transparent, veins infuscate. Costal margin biconvex, coupling lobe in concavity before wing midlength. ScRA apex level with $\mathrm{M}$ fork. $\mathrm{M}$ fork 1.2 times as long as CuA1 fork. Body 2.2 $\mathrm{mm}$ long; body and appendages pale fuscous, disc of mesonotum brown, femora and tibiae with brown longitudinal streaks. Head 1/2 as wide as pronotum; eyes large, hemispherical, emarginate below; head and coryphe deeply arcuately excavate posteriorly; posterior angles of coryphe at eye midlength. Coryphe trapezoidal, anteriorly less than $1 / 3$ head width and as wide as long in middle, depressed between high lateral carinae converging anteriorly, with strong median carina; coryphe curved into, and median carina continued onto, metope. Metope tricarinate, narrow and more depressed dorsally, more than twice widened ventrally; epistomal suture depressed. Scape elongate, obliquely produced anterodorsally, pedicel twice longer than scape, oval, ear-shaped, flattened dorsoventrally, scape + pedicel $2 / 3$ as long as head width. Pedicel covered with cuticular denticles, with more than ten plaque organs on each side. Low subantennal ridge running from epistomal suture to below antennal fovea. Postclypeus tricari- 


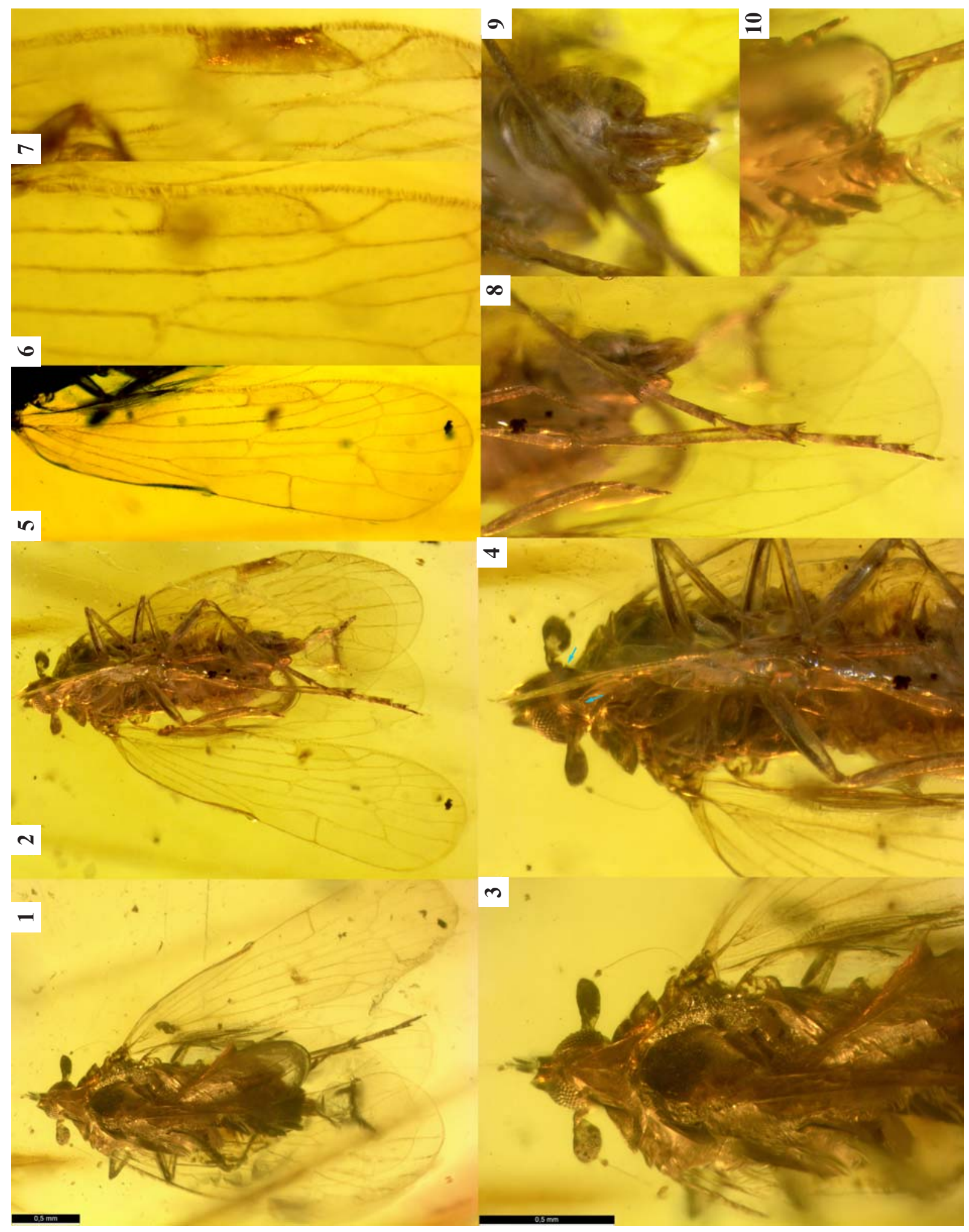

Figs 1-10. Derbachile hochae gen. et sp.n., holotype male, Burmese amber: 1 - habitus, dorsal; 2 - habitus, ventral; 3 - head and thorax, dorsal; 4 - head and thorax, ventral (arrows, subantennal ridges); 5 - tegmen, anterodorsal; 6-7 - C and stigmal cell: 6 - right, 7 - left tegmen; 8 - hind legs; 9 - genitalia, ventral; 10 - genitalia, dorsal. Scale bars: $0.5 \mathrm{~mm}$.

Рис. 1-10. Derbachile hochae gen. et sp.n., голотип, самец, бирманский янтарь: 1 - общий вид, сверху; 2 - общий вид, снизу; 3 - голова и грудь, сверху; 4 - голова и грудь, снизу (стрелки - подусиковые кили); 5 - переднее крыло, спереди-сверху; 6-7 С и стигмальная ячейка: 6 - правое переднее крыло, 7 - левое переднее крыло; 8 - задние ноги; 9 - гениталии, снизу; 10 гениталии, сверху. Длина масштабной линейки: 0,5 мм. 
nate, strongly narrowed towards unicarinate, laterally compressed anteclypeus. Rostrum reaching hind coxae, apical segment at least 4 times as long as wide. Pronotum 0.85 as wide as mesonotum, 1/3 as long in middle as wide, inverted $\mathrm{V}$ shaped, lateral margins acute, posterior margin sinuate medially; strongly elevated triangular tricarinate disc 1.4 as wide as long in middle, almost $1 / 2$ pronotum width. Mesonotum with nearly diamond-shaped disc, lateral carinae of disc strongly converging anteriorly, median carina absent. Legs very slender, femora and tibiae carinate. Hind tarsus nearly $2 / 3$ as long as tibia, tarsomere I longer than II+III; hind tibia and tarsomeres I and II weakly widened at apices; tibia with minute lateral tooth near base and larger one before midlength, and 8 apical teeth in uneven pecten; tarsomere I with 6 , II with 4 apical teeth. Claws slender. Male genital block small, anal tube rather short, styles directed caudally, with slender processes.

ETYMOLOGY. Named in honour of Prof. Hannelore Hoch, a brilliant entomologist, specialist on Cixiidae and other Fulgoroidea.

\section{Derbachile aschei Emeljanov et Shcherbakov, sp.n.} Figs 11-20, 25, 26.

MATERIAL. Holotype PIN 5608/123a, O , head and thorax dorsally eaten by some arthropod scavenger; paratypes PIN: 5608 $123 \mathrm{~b}$, male (?), in same amber piece as holotype, oxidized, antennae detached; 5608/129, sex unknown, fore legs malformed, most of head, hind legs and abdomen eaten away; 5608/130, female Burmese amber, Hukawng Valley, Kachin State, Myanmar; midCretaceous (probably Albian-Cenomanian).

DIAGNOSIS. Wings fuscous with darker shade along vein apices and pale at and near crossveins; body and legs fuscous; median carina of mesonotum incomplete; hind tibia with 3 lateral teeth.

DESCRIPTION. Tegmen 2.9 (paratype 5608/130) -3.6 mm long (paratype 5608/129), elongate, much widened distally, 2.3:1; membrane fuscous, finely transversely corrugate; veins darker, apical vein sections margined with darker shade; stigmal cell brown; pale: ScRA1, RA2a, RA2b, ir and RP near it, 2r-m, ima, MP2 base, $2 m-c u, \mathrm{CuA} 1$ from $2 m-c u$ to icua, icua and $\mathrm{CuA} 2$ shortly beyond it, postclaval crossvein, and truncate claval apex. Anterior margin almost straight near base and shallowly convex beyond; apical margin broadly rounded. Costal vein turning flat, ecarinate distad of ScR fork. C and ambient vein with minute sensory pits from base to apex of tegmen. ScR fork slightly distad of, and $\mathrm{CuA}$ fork more distad of, union of claval veins. Nodal $r-m$ distal to, or sometimes level with, nodal $m-c u$. MA fork much closer to nodal $r-m$ than to $2 r-m$. Medial cell long and narrow, about as large as cell anterodistal or cell distal to it. Crossvein on clavus between $\mathrm{CuP}$ and middle of Pcu. Claval furrow continued beyond truncate claval apex; $\mathrm{CuP}+\mathrm{Pcu}+1 \mathrm{~A}$ running close to posterior margin slightly beyond postclaval crossvein. Hind wing very large, almost 0.9 as long as tegmen, and very broad, 1.7:1, apex slightly not reaching apex of tegmen in repose; membrane pale fuscous, finely wrinkled; apical vein sections margined with darker shade, veins and coupling lobe brown, medial and claval folds pale. Costal margin biconvex, coupling lobe in concavity before wing midlength. ScRA apex proximad of level of M fork. M fork 1.3 times as long as CuA1 fork. Body 2.3 (paratype 5608/130) -2.9 mm long (paratype 5608/123b); body and appendages various shades of brown. Head $1 / 2$ as wide as pronotum; eyes large, ovoid, emarginate below; head and coryphe arcuately excavate posteriorly; posterior angles of coryphe close to eye midlength. Coryphe narrow trapezoidal, anteriorly less than $1 / 5$ head width and less than $1 / 2$ as wide as long in middle, slightly depressed between high lateral carinae markedly converging anteriorly, median carina obsolete; coryphe steeply curved into metope. Metope tricarinate, narrow and depressed between high lateral carinae, more than twice widened ventrally. Lateral ocellus anterior to eye. Scape rather short, not produced, pedicel 2.5 as long as scape, enlarged and slightly flattened, scape + pedicel $3 / 4$ as long as head width. Pedicel covered with cuticular denticles, with many plaque organs. Subantennal ridge absent. Postclypeus tricarinate, strongly narrowed towards unicarinate, laterally flattened anteclypeus. Rostrum reaching hind coxae, apical segment dark, 4 times as long as wide. Pronotum 0.9 as wide as mesonotum, 0.4 as long in middle as wide, inverted V-shaped, lateral margins acute, posterior margin sinuate medially; strongly elevated triangular tricarinate disc as wide as long in middle, almost 0.4 pronotum width. Mesonotum with nearly diamondshaped disc, lateral carinae of disc obsolete, converging anteriorly, weak median carina in anterior part. Legs slender, femora and tibiae carinate. Hind tarsus $2 / 3$ as long as tibia, tarsomere I longer than II+III; tibia and tarsomeres I and II markedly widened at apices; tibia with minute lateral tooth near base and two larger ones before $1 / 3$ and $2 / 3$ length, and 11 apical teeth in uneven pecten; tarsomere I with 9 , II with 6 apical teeth. Claws slender. Male genital block rather large, anal tube long, with lateral lobes, styles long, upcurved. Female genital block subtriangular in ventral aspect.

REMARKS. The specimens assigned to this species share the same general structure and colour pattern, but show significant size variation, indicating that they may belong to more than one closely related species, distinguishable only by the characters of male genitalia, as in the genus Cedusa Fowler, 1904.

ETYMOLOGY. Named in honour of Dr Manfred Asche, an eminent entomologist, specialist on Delphacidae and other Fulgoroidea.

\section{Genus Achiderbe Emeljanov et Shcherbakov, gen.n.}

TYPE SPECIES: Achiderbe obrienae Emeljanov et Shcherbakov, sp.n.

DIAGNOSIS. Distinct from Derbachile gen.n. in the clavus slightly more than $1 / 2$ wing length, ScR forking later than $\mathrm{CuA}$, stigmal cell not darkened, RA2 simple, RP with short fork, MA forking slightly earlier than MP, medial cell wide, icua proximal to $2 m-c u$, CuA1 straight there, 1 st procubital cell not expanded distally, clavus without crossvein, and hind wing not broad; lateral discal carinae of mesonotum subparallel, median carina well-developed; hind tibia apparently without lateral teeth.

COMPOSITION. Type species.

ETYMOLOGY. Free combination of generic names Achil$u s$ and Derbe; gender feminine.

Figs 11-20. Derbachile aschei sp.n., Burmese amber: 11-12 — holotype male, habitus, lateral; 13-14 - paratype male 5608/123b: 13 habitus, dorsal; 14 - head and thorax, dorsal; 15-16 - paratype 5608/129; 15 - habitus, ventral; 16 - stigmal cell; 17-20 - paratype female 5608/130; 17 — habitus, lateral; 18 - habitus, ventral; 19 - body, ventral; 20 - distal part of hind leg. Scale bars: 11-13, 15, 17, $18-1 \mathrm{~mm}, 14,19-0.5 \mathrm{~mm}, 16-0.2 \mathrm{~mm}$.

Рис. 11-20. Derbachile aschei sp.n., бирманский янтарь: 11-12 — голотип, самец, общий вид, сбоку; 13-14 - паратип, самец 5608/123b: 13 - общий вид, сверху; 14 - голова и грудь, сверху; 15-16 - паратип 5608/129; 15 - общий вид, снизу; 16 стигмальная ячейка; 17-20 — паратип, самка 5608/130; 17 - общий вид, сбоку; 18 - общий вид, снизу; 19 - тело, снизу; 20 дистальная часть задней ноги. Длина масштабной линейки: $11-13,15,17,18-1$ мм, 14, $19-0,5$ мм, $16-0,2$ мм. 


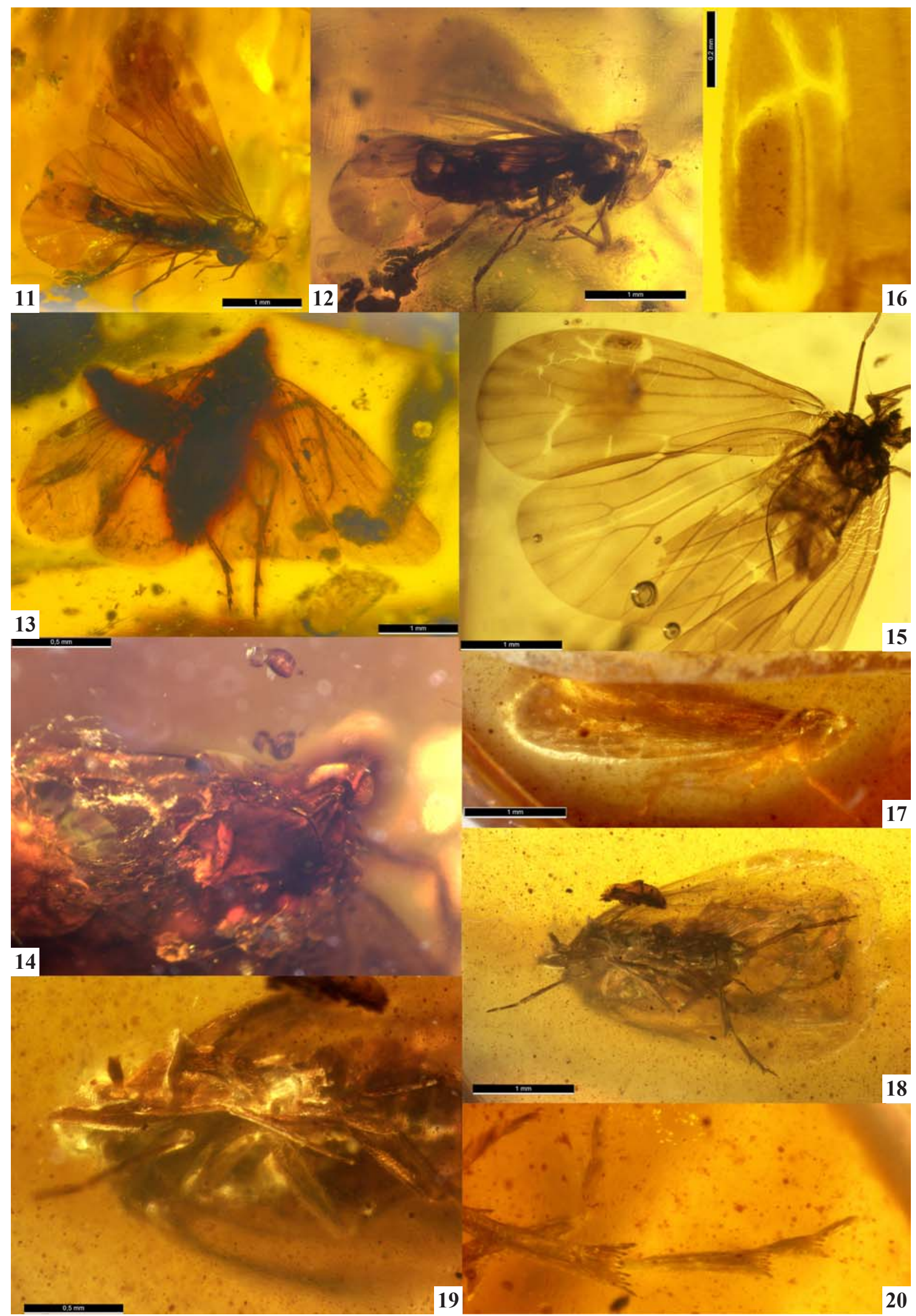


Achiderbe obrienae Emeljanov et Shcherbakov, sp.n. Figs 21-24, 28.

MATERIAL. Holotype PIN 5608/126, $\sigma^{x}$, most of head and dorsal part of thorax eaten by some arthropod scavenger, distal parts of hind legs polished away; syninclusions: 2 Empidoidea - Burmese amber, Hukawng Valley, Kachin State, Myanmar; mid-Cretaceous (probably Albian-Cenomanian)

DESCRIPTION. Tegmen $3.9 \mathrm{~mm}$ long, elongate, 2.8:1, fuscous with pale: irregular transverse bands proximally, crossveins and vein apices distally; stigmal cell pale at nodus, distally of same shade of brown as adjacent cells. Anterior margin shallowly convex near base and at nodus, almost straight between; apical margin obliquely rounded. Costal vein thickened near base, turning flat, slender distad of $\mathrm{ScR}+\mathrm{M}$ stalk; $\mathrm{C}$ and ambient vein with sensory pits, better developed at base, traceable up to apex of tegmen. ScR fork much distad of, and $\mathrm{CuA}$ fork distad of, union of claval veins. Nodal $r-m$ level with nodal $m-c u$. MA fork about halfway from nodal $r-m$ to $2 r-$ $m$. Medial cell long and broad, much larger than cell distal to it or cell anterodistal to it. Clavus truncate at apex, without crossvein. Hind wing ca. $2.9 \mathrm{~mm}$ long, $1.2 \mathrm{~mm}$ wide, not large, 0.75 as long as tegmen, and narrow, $2.4: 1$, apex considerably not reaching apex of tegmen in repose; membrane fuscous, veins brown. Costal margin biconvex, coupling lobe in concavity beyond wing midlength. ScRA apex proximad of level of $\mathrm{M}$ fork. $\mathrm{M}$ fork twice as long as $\mathrm{CuA} 1$ fork. Body $3.6 \mathrm{~mm}$ long; body and appendages various shades of brown. Antero- dorsal part of head not preserved. Scape elongate, obliquely produced anterodorsally, pedicel thrice longer than scape, paddle-shaped, flattened, scape + pedicel about as long as clypeus. Pedicel covered with cuticular denticles, with many plaque organs. Subantennal ridge absent. Postclypeus strongly narrowed towards unicarinate, laterally flattened anteclypeus. Rostrum reaching hind coxae, apical segment dark, about 4 times as long as wide. Pronotum not preserved. Mesonotum with lateral discal carinae strong, subparallel, median carina well-developed. Legs rather short and stout, tibiae tetrahedral, somewhat flattened, hind tibiae without lateral teeth in proximal half (their distal half and hind tarsi not preserved), claws strong. Abdomen slightly inflated, laterotergites rectangular. Male genital block rather small; pygofer ventrally sinuate with median depression between two oblique carinae; anal tube rather long, with posterolateral lobes; styles short and broad, their apices bent mediad.

ETYMOLOGY. Named in honour of Dr Lois B. O'Brien, a worldwide known entomologist, specialist on Fulgoroidea.

\section{Discussion}

On the classification of Derbidae. Frederick Muir [1913] divided Derbidae into six groups and subgroups based almost exclusively on the venation and relative size of wings: I, Cenchrea group; II, Otiocerus group; III,

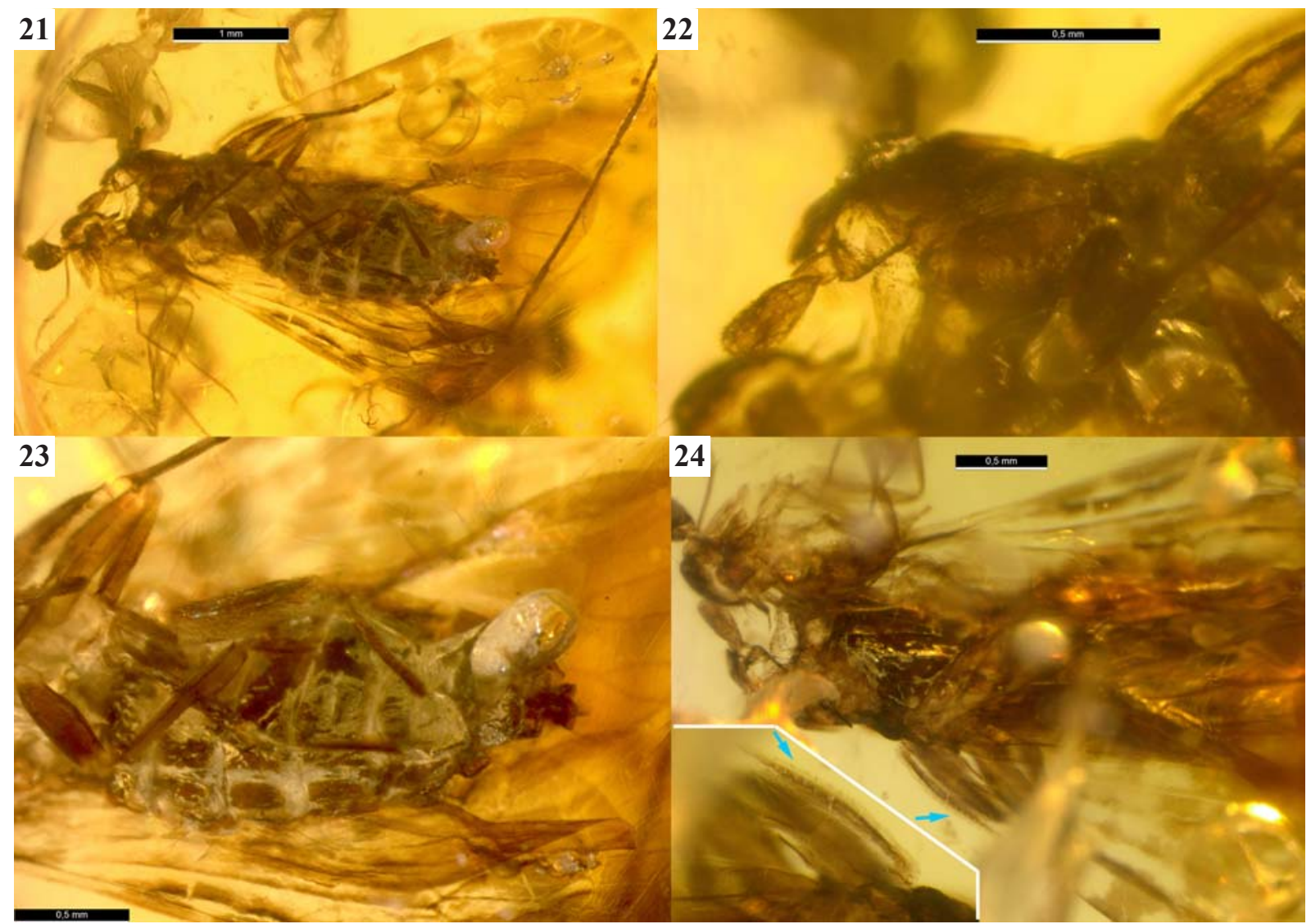

Figs 21-24. Achiderbe obrienae gen. et sp.n., holotype male, Burmese amber: 21 — habitus, ventral; 22 - head, lateroventral; 23 abdomen, lateroventral; 24 - thorax and bases of wings, laterodorsal (inset, base of tegmen, rotated $180^{\circ}$; arrows, sensory pits on base of C). Scale bars: $21-1 \mathrm{~mm}, 22-24-0.5 \mathrm{~mm}$.

Рис. 21-24. Achiderbe obrienae gen. et sp.n., голотип, самец, бирманский янтарь: 21 — общий вид, снизу; 22 - голова, снизусбоку; 23 - брюшко снизу-сбоку; 24 - грудь и основания крыльев, сверху-сбоку (врезка, основание переднего крыла, повернуто на $180^{\circ}$; стрелки - сенсорные ямки на основании С). Длина масштабной линейки: $21-1$ мм, 22-24 - 0,5 мм. 
with Sikaiana and Zoraida subgroups; IV, with Derbe + Mysidia and Rhotana subgroups. Later he created four subfamilies and two tribes, Cenchreinae, Otiocerinae, Derbinae (Derbini including Zoraida, Sikaianini) and Rhotaninae [Muir, 1917], and then rearranged these taxa as six tribes of two subfamilies, Zoraidinae (Zoraidini, Sikaianini) [Muir, 1918a] and Derbinae (Derbini, Rhotanini, Cenchreini, Otiocerini) [Muir, 1918b]. Fennah [1952] classified Derbidae into the same six tribes without grouping them into subfamilies. Emeljanov [1992, 1995] revised the family classification using additional characters, first of all sensory pits on the body and tegmina, and reconstructed phylogeny for the family. He divided Derbidae into three subfamilies, including Otiocerinae (= Zoraidinae) and the new subfamily Cedusinae, and proposed a series of new tribes and subtribes: Ipsnolini, Goneokarellini, Phrygiini, Vinatini, Cedusini (including subtribe Eocenchreina), Cedochreini, Dawnarioidini, Nicertini, Kamendakini, Patarini, Neocyclocarini and Phenicini, sinking Mysidiini (created by Broomfield [1985]) under Derbini as a subtribe. The Eocene tribe Ptychoptilini, described in Achilidae by Emeljanov [1990], was later moved to Derbidae [Bourgoin, 2020]. Emeljanov and Fletcher [2004] transferred the tribe Breddiniolini from Achilidae to Derbidae Cedusinae based on the structure of male genitalia, and by priority, the name of the subfamily should be changed to Breddiniolinae Fennah, 1950, stat.n. (= Cedusinae Emeljanov, 1992, syn.n.). Banaszkiewicz and Szwedo [2005] added one more tribe, Aquaeliciini.

The subfamily Derbinae was separated from Cedusinae by a single character, namely the presence of sensory pits in adult [Emeljanov, 1995]. Giving such a great taxonomic value to sensory pits is unique among Fulgoroidea. Development of sensory pits was used as the principal character to diagnose tribes in Orgeriinae and Caliscelinae [Emeljanov, 1969, 2008b] and (in conjunction with other characters) subfamilies in Meenoplidae [Muir, 1930]. The presence of sensory pits on the head and on the $\mathrm{C}$ and clavus in the tegmen was the only criterion for distinguishing Cedochreini and Cenchreini (Derbinae) from Cedusini (Cedusinae): the pits are absent in Cedusini, present only on the basal part of $\mathrm{C}$ in Cedochreini, and on the head, $\mathrm{C}$ and $\mathrm{Pcu}$ in Cenchreini [Emeljanov, 1992, 1995]. However, there are exceptions: in some Cedochreini the pits are developed also at the scutellar margin of clavus (Cedochrusa Emeljanov, 2008) [Emeljanov, 2008a, fig. 12], and vice versa, the pits on tegmen are restricted to the basal part of $\mathrm{C}$ also in some Cenchreini (Dawnaria girdlestoni (Muir, 1913)), Nicertini (Leptaleocera coccinea Muir, 1913) and Otiocerini (Paralyricen jepsoni Muir, 1913; Platocera annulipes Muir, 1913, Pyrrhoneura immaculata Muir, 1913, etc.) [Muir, 1913, pl. 3].

Another important set of character changes at the transition from the basal derbid tribes to Derbinae is associated with the apex of clavus, postclaval area and postclaval crossvein. Achilidae and the most primitive, still achilid-like derbids (grade A) have tegmina not as long as the body, their postnodal parts overlapping in repose (often short) and sometimes with extra folding, apex of clavus transversely or obliquely truncate, $\mathrm{CuP}$ sharply bent posteriorly near the apex, Pcu+1A joining $\mathrm{CuP}$ there, $\mathrm{CuA} 2$ reaching apical margin, claval furrow continued into long and wide postclaval area, and postclaval crossvein long and transverse. Somewhat more derived derbids that had lost the achilid habitus (grade B), have the tegmina longer than the body length, steeply tectiform in repose, CuP nearly straight apically, and $\mathrm{Pcu}+1 \mathrm{~A}$ joining either CuP near apex (Cedusini Eocenchreina, Cedochreini, some Cenchreini - e.g. Goneokara Muir, 1913, Agoo Bahder et Bartlett, 2019), or 2A or their junction (cixiid condition restored: Cedusina, Dawnarioidini, other Cenchreini - e.g. Basileocephalus Kirkaldy, 1906, Dawnaria Distant, 1911). Further transformations of the claval region occur in still more derived derbids: $\mathrm{CuP}$ after junction with $\mathrm{Pcu}+1 \mathrm{~A}$ running along posterior margin up to postclaval crossvein, clavus open, postclaval area short and narrow, $\mathrm{CuA} 2$ joining posterior margin, postclaval crossvein short and oblique. This condition, recorded already in a few Cenchreini (some Phaciocephalus Kirkaldy, 1906, Herpis Stål, 1862), is further developed in higher Derbidae [Fennah, 1952].

The characters that unite all Derbidae are the fusion of tergite IX with the anal tube in males, and probably also peculiar wax pores on the abdomen. In the evolution of Derbidae, there was a transformation of the basal, achilid-like forms into higher derbids through accumulation of derived characters. Accordingly, the tribes of Derbidae were arranged in a phylogenetic sequence [Emeljanov, 1995]. The character changes that have occurred from primitive tribes to typical derbids are as follows:

(1) shortening of the apical segment of rostrum - at least thrice as long as wide in Breddiniolini, Ipsnolini, Goneokarellini, Vinatini, Ptychoptilini, Derbachilini trib.n.; at most twice in other derbids (except for $A r$ chara Metcalf, 1945 of Otiocerini) [Fennah, 1952];

(2) reduction of lateral teeth on hind tibia - four or three teeth in Breddiniolini; three or two in Derbachile gen.n.; two in Vinatini; one tooth in Ipsnolini, Goneokarellini, Phrygiini and Eocenchrea Muir, 1913 (Cedusini Eocenchreina); no teeth in other derbids, except Zoraidini and Sikaianini;

(3) reduction of subapical setae on apical pectens of hind tarsomeres - setae present in Breddiniolini and Ipsnolini; absent in Derbachile gen.n. and other derbids;

(4) medial shorthening of pronotum and reduction of its disc — pronotal disc elevated, tricarinate, triangular, nearly as long as wide in Ipsnolini, Vinatini, Ptychoptilini, Derbachile gen.n.; much shorter in Goneokarellini, Phrygiini, some Cenchreini; not elevated, ecarinate in other derbids;

(5) reduction of $\mathrm{M}$ fork in hind wing $-\mathrm{M}$ forked before $r-m$ in Breddiniolini, Derbachilini trib.n.; beyond $r-m$ in Ipsnolini, Phrygiini, Cedochreini; simple in other primitive derbids;

(6) reduction of $\mathrm{CuA} 1$ fork in hind wing - $\mathrm{CuA} 1$ forked before $m-c u$ in Breddiniolini; beyond $m-c u$ in Ipsnolini, Goneokarellini, Phrygiini, Derbachilini trib.n.; simple in other derbids; 
(7) modification of antenna - enlarged and somewhat flattened in Derbachilini trib.n.; enlarged in Vinatini, Derbini, and flattened in some Otiocerinae;

(8) development of subantennal lobe - ridge at lorogenal boundary in Phrygiini [Emeljanov, 1995]; low ridge in Derbachile hochae sp.n.; lobe in Cedusini, Cedochreini, Cenchreini, most Otiocerinae;

(9) shortening of ScRA in hind wing - in Cedusini (except Emeljanovedusa Szwedo, 2006 from Baltic amber) and higher tribes;

(10) increase of wing/body size ratio - tegmen length greater than body length in Breddiniolini, Derbachilini trib.n., and in Cedusini and higher tribes;

(11) loss of tegminal overlap and truncate apex of clavus - tegmina overlapping, clavus truncate in Breddiniolini, Ipsnolini, Goneokarellini, Phrygiini, Vinatini, Ptychoptilini and Derbachilini trib.n.; tegmina not overlapping, clavus more acute or open in Cedusini and higher tribes;

(12) development of sensory pits in adults - on C in tegmen (sometimes on its base only) in Derbachilini trib.n., Dawnarioidini, and some Cedochreini, Cenchreini, Nicertini and Otiocerini; on $\mathrm{C}$ and/or other veins and/or head in higher tribes.

Therefore, the transformation of achilid-like ancestors into typical derbids was rather gradual. This process may be termed 'derbization of achilids', by analogy with other '-zations' [Shcherbakov, 2007a, 2012; Gnezdilov, 2013].

The tribe Cedusini is transitional from Breddiniolinae to Derbinae. This tribe is similar to Cenchreini and other Derbinae in most of the above characters, except the absence of sensory pits in adult, and in some genera the long ScRA in hind wing or one lateral tooth on hind tibia [Szwedo, 2006]. The sensory pits appear in adults due to retention of the nymphal pits, so they are especially susceptible to reversals in the evolution. The degree of development of sensory pits on the tegmen is quite variable in Cenchreini, and e.g. in Dawnaria they are restricted to the basal part of $\mathrm{C}$, so there is only one step to their loss. Hence, it seems possible that sensory pits were secondarily lost in adult Cedusini, or even that their appearance and loss in adult Derbidae occurred more than once. The new Cretaceous tribe represents another plausible transition from achilid-like basal derbids to the higher tribes (see below).

Systematic position of the new tribe. The new taxa from Burmese amber are recognized as derbids based on the small size of body relative to wings, modified antennae, presence of sensory pits on the $\mathrm{C}$ of tegmen, venation achilid-like (but without bends on $\mathrm{R}$ and $\mathrm{CuA}$ branches or a transverse fold at the nodus in tegmen, characteristic of Achilidae), and also the enlarged 1st procubital cell, darkened stigmal cell, RA2 with short fork and recurrent RA2a in Derbachile gen.n., rudimentary subantennal ridge in D. hochae sp.n., and fuscous colouration of tegmina with pale crossveins in D. aschei sp.n. Each of these characters taken alone is found also outside Derbidae, but in such a combination they occur only in this family. The fuscous colouration of tegmina with pale crossveins and a dark stigmal cell is found e.g. in the subtribe Cedusina, and short recurrent RA2a in some Cedusina, Kamendakini, Patarini and Aquaeliciini.

In the venation of tegmen (including a long postnodal part and longitudinal branches of $\mathrm{M}$ and $\mathrm{CuA}$ ) and sensory pits on the base of $\mathrm{C}$, the new tribe is similar to the Central American tribe Cedochreini, but differs in the more complete hind wing venation, long apical segment of rostrum, and hind tibia with lateral teeth. These latter characters place the new tribe among the most primitive derbids.

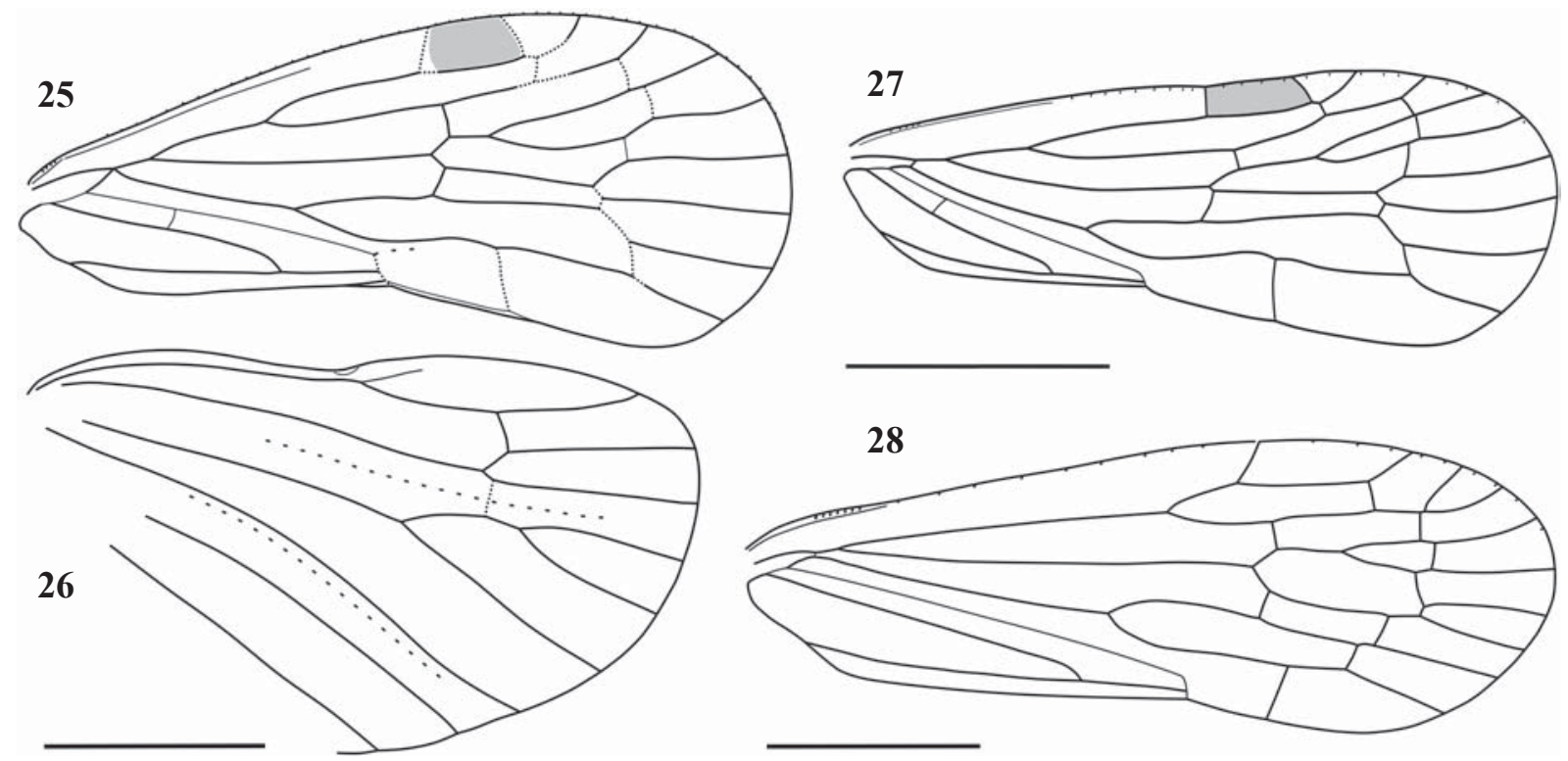

Figs 25-28. Venation of Derbachilini: 25-26 — Derbachile aschei sp.n.: 25 — tegmen; 26 — hind wing; 27 - Derbachile hochae gen. et sp.n., tegmen; 28 - Achiderbe obrienae gen. et sp.n., tegmen. Scale bars: $1.0 \mathrm{~mm}$.

Рис. 25-28. Жилкование Derbachilini: 25-26 — Derbachile aschei sp.n.: 25 — переднее крыло; 26 - заднее крыло; 27 — Derbachile hochae gen. et sp.n., переднее крыло; 28 - Achiderbe obrienae gen. et sp.n., переднее крыло. Масштабные линейки: 1,0 мм. 
In the presence of the cup-pcu crossvein on clavus, Derbachile gen.n. is more primitive than all other derbids and similar to some Cixiidae, Delphacidae and Kinnaridae and primitive Fulgoridae [Emeljanov, 2013].

Derbachile gen.n. is distinct from all other derbids also in the crossvein icua shifted much distal to $2 m-c u$, and the 1st procubital cell markedly widened distally. The icua is shifted slightly distal to $2 m-c u$ (but 1 st procubital cell narrow) in some species of the genus Anticedusa (Costa Rican A. loisae Emeljanov, 2008) and some specimens of New Zealandian Eocenchrea maorica (Kirkaldy, 1909) [Synave, 1973: 146] (both of Cedusini Eocenchreina), whereas in the other species or specimens it is proximal or interstitial [Muir, 1913: pl. 3; Emeljanov, 2008: 913]. The icua is interstitial to $2 m$ $c u$ in both genera of the tribe Cedochreini.

In the primitive, achilid-like hind wing venation, the new tribe is similar to, and more primitive than, the South American tribes Ipsnolini and Phrygiini (in these latter the $\mathrm{M}$ is forked distal to crossveins).

In the enlarged and more or less flattened pedicel and sometimes also obliquely produced scape, Derbachilini trib.n. are similar to Otiocerini. Microscopic cuticular denticles densely covering pedicel in the new genera are similar to those found in Cixiidae, Meenoplidae, Kinnaridae, Achilixiidae and some Derbidae [Liang, 2001: 222, fig. 6].

In the long apical segment of rostrum, the new tribe is similar to the tribes Breddiniolini (Afro-Australo-Melanesian), Ipsnolini and Goneokarellini (Chilean), Vinatini (Oriental), and Ptychoptilini from Baltic amber.

Derbachile gen.n. is similar to Breddiniolini and Vinatini in the presence of 2-3 lateral teeth on the hind tibia, to Ipsnolini, Vinatini and Ptychoptilini in the elevated, long, tricarinate disc of pronotum, and to Phrygiini in the ridge under antenna.

In the $\mathrm{CuP}+\mathrm{Pcu}+1 \mathrm{~A}$ continued along posterior margin and joining it beyond postclaval crossvein in the tegmen, D. aschei sp.n. is similar to some Cenchreini (e.g. Herpis) and Nicertini.

Thus, in nine of the above-mentioned 12 characters the tribe Derbachilini trib.n. agrees with achilid-like tribes of Breddiniolinae, in the increased wing/body size ratio rather with higher tribes, in the presence of sensory pits on $\mathrm{C}$ with some Derbinae, and in the enlarged flattened antennae with Otiocerinae. The new tribe is among the most primitive Derbidae, though its type genus shows some similarity (possibly homoplastic) to the basal tribe Cedochreini of the moderately advanced subfamily Derbinae. In shallowly tectiform tegmina overlapping beyond truncate claval apices in repose, Derbachilini trib.n. is still at the grade A, though in tegmina and wings relatively large (and the clavus in the type genus less than $1 / 2$ tegmen) it is already at the base of the grade B (see above). The new tribe is transitional between the two subfamilies: in the arrangement of sensory pits and venation, it is close to the subfamily Derbinae, especially to the tribe Cedochreini, but most of the other characters firmly place it in the subfamily Breddiniolinae.
The second new genus, Achiderbe gen.n. is incompletely known and lacks some salient characters of Derbachile gen.n., although in general it is similar to the latter in venation and body structure. Therefore, it is assigned to the new tribe tentatively.

On biology of Burmese amber Derbidae. The Burmite derbids are tiny insects, like many other members of the family that are usually small planthoppers, including the primitive tribes, most Cenchreini and especially Rhotanini, while some Derbini and Zoraidini are much larger. D. hochae sp.n. with tegmen $2.6 \mathrm{~mm}$ long is at the lower size limit for the family, along with some Rhotanini [Zelazny, Webb, 2011].

Modern adult Derbidae feed mainly on monocots, especially palms, and woody dicots, rarely on ferns, and most species were reported from only one host plant genus [Wilson et al., 1994]. Their nymphs feed on fungi in rotting wood and decaying organic debris [Yang, Yeh, 1994; Wheeler, Wilson, 1996; Howard et al., 2001]. A similar lifestyle was possible for the Burmite derbids, which were not uncommon in a Cretaceous tropical forest. Some twenty angiosperm species are recorded from Burmese amber, including trees and monocots [Liu et al., 2018; Paleobiota of Burmese amber, 2020]. Palms and other monocots are discovered in the Early Cretaceous of Gondwana [Martínez et al., 2016; Coiffard et al., 2019]. Therefore, it is possible that the earliest Derbidae already enjoyed their favourite hosts $100 \mathrm{Ma}$ ago.

Acknowledgements. We are grateful to Alexey Bashkuev (PIN) for attracting our attention to these fossils, and Eugeny Karasev and Tatiana Foraponova (PIN) for providing microscopic facilities. The study was performed in the framework of the Russian State Research project no. AAAA-A19119020690101-6 and the Russian Foundation for Basic Research project no. 18-04-00322.

\section{References}

Anufriev G.A., Emeljanov A.F. 1988. [Suborder Cicadinea (Auchenorrhyncha)]//Opredelitel' nasekomykh Dal'nego Vostoka SSSR. Vladivostok. Vol.2. P.12-495 [in Russian].

Banaszkiewicz M., Szwedo J. 2005. Notes on Otiocerinae with description of a new tribe from Madagascar and Africa (Hemiptera: Fulgoromorpha: Derbidae) // Ann. Zool. Vol.55. P.223-241.

Bourgoin T. 2020. FLOW (Fulgoromorpha Lists on The Web): a world knowledge base dedicated to Fulgoromorpha. Version 8, updated 2020-05-07. http://hemiptera-databases.org/flow/ (accessed Aug. 13, 2020).

Broomfield P.S. 1985. Taxonomy of Neotropical Derbidae in the new tribe Mysidiini (Homoptera) // Bull. Brit. Mus. (Nat. Hist.) Entomol. Vol.50. P.1-152.

Coiffard C., Kardjilov N., Manke I., Bernardes-de-Oliveira M.E. 2019. Fossil evidence of core monocots in the Early Cretaceous // Nature plants. Vol.5. P.691-696.

Emeljanov A.F. 1969. Reclassification of Palearctic planthoppers of the subfamily Orgeriinae (Homoptera, Dictyopharidae) // Entomol. Rev. Vol.48. No.2. P.189-198.

Emeljanov A.F. 1990. [A new genus and a new tribe of the family Achilidae (Homoptera, Cicadina) from the Baltic amber] // Vestn. Zool. No.1. P.6-10 [in Russian].

Emeljanov A.F. 1992. [Two new tribes, a new genus and a new species of the family Derbidae (Homoptera, Fulgoroidea)] // Vestn. Zool. No.4. P.19-23 [in Russian]. 
Emeljanov A.F. 1994. The first fossil find of the family Derbidae and a redescription of the Paleogene genus Hooleya Cockerell (Achilidae) (Insecta: Homoptera, Fulgoroidea) // Paleontol. J. Vol.28 No.3. P.92-101.

Emeljanov A.F. 1995. [On the system and phylogeny of the family Derbidae (Homoptera, Cicadina)] // Entomol. Obozr. 1994 Vol.73. P.783-811, 946-947 [in Russian, English translation: Entomol. Rev. 1996. Vol.75. No.2. P.70-100].

Emeljanov A.F. 2002. A record of Derbidae (Insecta: Homoptera: Fulgoroidea) in the Miocene of the Northern Caucasus // Paleontol. J. Vol.36: P.277-278.

Emeljanov A.F. 2008a. Two new genera of the family Derbidae from the New World, with description of recent and an extinct Miocene new species (Homoptera, Fulgoroidea) // Entomol. Rev. Vol.88. P.910-915.

Emeljanov A.F. 2008b. [New species of the genus Peltonotellus Puton (Homoptera, Caliscelidae) from Kazakhstan, Middle and Central Asia] // Tethys Entomol. Res. Vol.16. P.5-12 [in Russian].

Emeljanov A.F. 2013. A new species of the genus Pibrocha Kirkaldy (Homoptera, Fulgoridae) with notes on the systematics of the subfamily Dichopterinae and with description of a new tribe // Entomol. Rev. Vol.93. P.775-780.

Emeljanov A.F., Fletcher M.J. 2004. Hemielissum evansi, a new genus and species of Breddiniolini (Hemiptera: Fulgoromorpha), being the first Australian record of the tribe, with a discussion of the taxonomic position of the Breddiniolini // Aust. J. Entomol. Vol.43. P.38-42.

Emeljanov A.F., Shcherbakov D.E. 2000. Kinnaridae and Derbidae (Homoptera, Fulgoroidea) from the Dominican amber // N. Jb. Geol. Paläont. Mh. No.7. P.438-448.

Emeljanov A.F., Shcherbakov D.E. 2018. The longest-nosed Mesozoic Fulgoroidea (Homoptera): A new family from mid-Cretaceous Burmese amber // Far East. Entomol. Vol.354. P.1-14.

Fennah R.G. 1952. On the generic classification of Derbidae (Fulgoroidea), with descriptions of new Neotropical species // Trans. R. Ent. Soc. London. Vol.103. No.4. P.109-170.

Gnezdilov V.M. 2013. "Issidisation" of fulgoroid planthoppers (Homoptera, Fulgoroidea) as a case of parallel adaptive radiation // Entomol. Rev. Vol.93. P.825-830.

Howard F.W., Weissling T.J., O’Brien L.B. 2001. The larval habitat of Cedusa inflata (Hemiptera: Auchenorrhyncha: Derbidae) and its relationship with adult distribution on palms // Florida Entomol. Vol.84. P.119-122.

Jiang T., Szwedo J., Wang B. 2018. A giant fossil Mimarachnidae planthopper from the mid-Cretaceous Burmese amber (Hemiptera, Fulgoromorpha) // Cretac. Res. Vol.89. P.183-190.

Liang A.P. 2001. Morphology of antennal sensilla in Achilixius sandakanensis Muir (Hemiptera: Fulgoromorpha: Achilixiidae) with comments on the phylogenetic position of the Achilixiidae // Raffles Bull. Zool. Vol.49. P.221-226.

Liu Z.J., Huang D., Cai C., Wang X. 2018. The core eudicot boom registered in Myanmar amber // Sci. Rep. Vol.8. 16765.

Luo C., Jiang T., Wang B., Xiao C. 2020a. A new species of Burmissus (Hemiptera: Fulgoromorpha: Mimarachnidae) from mid-Cretaceous Burmese amber // Cretac. Res. 104417.

Luo C., Jiang T., Szwedo J., Wang B., Xiao C. 2020b. A new planthopper family Katlasidae fam. nov. (Hemiptera: Fulgoromorpha: Fulgoroidea) from mid-Cretaceous Kachin amber // Cretac. Res. 104532

Martínez L.C., Archangelsky S., Prámparo M.B., Archangelsky A. 2016. Early Cretaceous palm pollen tetrads from Patagonia, Argentina // Cretac. Res. Vol.59. P.129-139.

Muir F.A.G. 1913. On some new species of leafhoppers. Part II. Derbidae // Bull. Hawaiian Sugar Planters' Assoc. Exp. Stat Div. Entomol. Vol.12. P.28-92.

Muir F.A.G. 1917. The Derbidae of the Philippine Islands // Philippine Journal of Science. Ser.D. Vol.12. P.49-104.

Muir F.A.G. 1918a. Notes on the Derbidae in the British Museum collection.-I. Zoraidinae // Ent. Mon. Mag. Vol.54. P.173177; 202-207.

Muir F.A.G. 1918b. Notes on the Derbidae in the British Museum collection.-II. Derbidae// Ent. Mon. Mag. Vol.54. P.228-243.

Muir F.A.G. 1930c. On the classification of the Fulgoroidea // Annals and Magazine of Natural History. Ser. 10. Vol.6. P.461-478.

Paleobiota of Burmese amber, 2020. https://en.wikipedia.org/wiki/
Paleobiota of Burmese amber $\sigma^{\top}$ Angiospermae (accessed Aug. 30, 2020).

Shcherbakov D.E. 2000. The most primitive whiteflies (Hemiptera; Aleyrodidae; Bernaeinae subfam. nov.) from the Mesozoic of Asia and Burmese amber, with an overview of Burmese amber hemipterans // Bull. Nat. Hist. Mus. London (Geol.). Vol.56. P.29-37.

Shcherbakov D.E. 2007a. An extraordinary new family of Cretaceous planthoppers (Homoptera: Fulgoroidea) // Russ. Entomol. J. Vol.16. P.139-154.

Shcherbakov D.E. 2007b. Mesozoic spider mimics - Cretaceous Mimarachnidae fam.n. (Homoptera: Fulgoroidea) // Russ. Entomol. J. Vol.16. P.259-264.

Shcherbakov D.E. 2012. More on Mesozoic Membracoidea // Russ. Entomol. J. Vol.21. P.15-22.

Shcherbakov D.E. 2017. First record of the Cretaceous family Mimarachnidae (Homoptera: Fulgoroidea) in amber // Russ. Entomol. J. Vol.26. P.389-392.

Shi G., Grimaldi D.A., Harlow G.E., Wang J., Wang J., Yang M., Lei W., Li Q., Li X. 2012. Age constraint on Burmese amber based on U-Pb dating of zircons // Cretac. Res. Vol.37. P.155-163.

Song Z.S., Xu G.H., Liang A.P., Szwedo J., Bourgoin T. 2019. Still greater disparity in basal planthopper lineage: A new planthopper family Yetkhatidae (Hemiptera, Fulgoromorpha, Fulgoroidea) from mid-Cretaceous Myanmar amber // Cretac. Res. Vol.101. P 47-60.

Stroiński A., Szwedo J. 2002. An overview of Fulgoromorpha and Cicadomorpha in East African copal (Hemiptera) // Denisia. Vol.4. N.F. No.176. P.57-66.

Synave H. 1973. Monographie des Derbidae Africains (HomopteraFulgoroidea) // Etudes du Continent Africain Vol.2. P.1-223.

Szwedo J. 2004a. A new Derbidae planthopper Copallinges chiapasensis gen. et sp.n. (Hemiptera: Fulgoromorpha) from Oligocene/Miocene Mexican amber // Pol. Pismo Entomol. Vol.73. P.291-298.

Szwedo J. 2004b. Niryasaburnia gen. nov. for 'Liburnia' burmitina Cockerell, 1917, from Cretaceous Myanmar (Burmese) amber (Hemiptera, Fulgoromorpha: Achilidae) // J. Syst. Palaeontol. Vol.2. P.105-107.

Szwedo J. 2005. Notes on Otiocerini with a second record of Derbidae in Eocene Baltic amber (Hemiptera: Fulgoromorpha: Derbidae) // Insect Syst. Evol. Vol.36. P.161-172.

Szwedo J. 2006. First fossil record of Cedusini in the Eocene Baltic amber with notes on the tribe (Hemiptera: Fulgoromorpha: Derbidae) // Russ. Entomol. J. Vol.15. P.327-333.

Szwedo J., Stroiński A. 2001. Ptychogroehnia reducta gen. and sp. nov. of the fossil tribe Ptychoptilini from the Eocene Baltic amber (Hemiptera: Fulgoroidea: Achilidae) // Ann. Zool. Vol.51. P.95-101.

Westerweel J., Roperch P., Licht A., Dupont-Nivet G., Win Z., Poblete F., Ruffet G.; Swe H.H., Thi M.K., Aung D.W. 2019. Burma Terrane part of the Trans-Tethyan arc during collision with India according to palaeomagnetic data // Nat. Geosci. Vol.12. P.863-868.

Wheeler A.G. Jr., Wilson S.W. 1996. Planthoppers of pitch pine and scrub oak in pine barrens communities (Homoptera: Fulgoroidea) // Proc. Entomol. Soc. Wash. Vol.98. P.100108.

Wilson S.W., Mitter C., Denno R.F., Wilson M.R. 1994. Evolutionary patterns of host plant use by delphacid planthoppers and their relatives // Planthoppers. Boston, MA: Springer. P. 7-113.

Xing L., Qiu L. 2020. Zircon U-Pb age constraints on the midCretaceous Hkamti amber biota in northern Myanmar // Palaeogeogr. Palaeoclimat. Palaeoecol. 109960.

Yang C.T., Yeh W.B. 1994. Nymphs of Fulgoroidea (Homoptera: Auchenorrhyncha) with descriptions of two new species and notes on adults of Dictyopharidae // Chin. J. Entomol. Spec. Publ. Vol.8. P.1-189.

Zelazny B., Webb M. D. 2011. Revision of the planthopper tribe Rhotanini (Hemiptera: Auchenorrhyncha: Derbidae) // Zootaxa. Vol.3071. P.1-307.

Zhang X., Ren D., Yao Y. 2017. A new species of Foveopsis Shcherbakov (Hemiptera: Fulgoromorpha: Fulgoroidea: Perforissidae) from mid-Cretaceous Burmese amber // Cretac. Res. Vol.79. P.35-42.

Zhang X., Ren D., Yao Y. 2019. A new family Jubisentidae fam. nov. (Hemiptera: Fulgoromorpha: Fulgoroidea) from the mid-Cretaceous Burmese amber // Cretac. Res. Vol.94. P.1-7. 